\title{
Involvement of gamma aminobutyric acid in the anticonvulsant effect of the leaf methanol extract of Ruta graveolens L. (Rutaceae) in mice
}

\section{A.H. Ahmad and G.J. Amabeoku}

Abstract: The possible involvement of gamma aminobutyric acid (GABA), in the anticonvulsant effect of Ruta graveolens L. was investigated by studying the effect of the leaf methanol extract against seizures elicited by either pentylenetetrazole (PTZ), bicuculline, picrotoxin or N-Methyl-DL-Aspartic acid (NlvIDLA) in mice. Leaf methanol extract of Ruta graveolens, phenobarbitone, diazepam and muscimol significantly antagonized seizures induced by PTZ, bicuculline or picrotoxin. Combined treatment of sub- effective doses of $R$. graveolens and muscimol significantly antagonized seizures induced by PTZ, bicuculline or picrotoxin. Dimethylsulfoxide (DMSO) or phenytoin did not significantly affect the seizures produced by PTZ, bicuculline or picrotoxin. Ruta graveolens, phenobarbitone, diazepam, phenytoin or DMSO did not significantly affect seizures produced by NlvIDLA. LY233053 significantly antagonized seizures produced by NlvIDLA. Combined treatment of sub-effective doses of LY233053 and Ruta graveolens did not significantly alter NlvIDLA-induced seizures. The phytochemical qualitative analysis of the plant species showed the presence of tannins, cardiac glycosides, saponins, flavonoids, triterpene steroids and alkaloids. The LD50 value obtained following oral administration of the leaf methanol extract of $R$. graveolens was above $4000 \mathrm{mg} \mathrm{kg-}^{1}$. The HPLC fingerprint of the plant species revealed certain characteristic peaks at 350 run. The data obtained in this study, indicate that the leaf methanol extract of $R$. graveolens has anticonvulsant activity. The data obtained also indicate that GABA mechanism may probably be involved in the anticonvulsant effect of the plant extract. The relatively high LD50 obtained for the plant species, given orally, indicates that it is safe in mice.

\section{Introduction}

Epilepsy is a worldwide neurological disorder which 1s also prevalent in South Africa. Besides the use of standard medicines to manage and treat the condition effectively, medicinal plants have been used especially in rural commmrities by traditional medicine practitioners to manage and treat epilepsy (Van Wyk et al., 1997; Wat 1967). One of such medicinal plants is Ruta graveolens L. 
The plant species originated from the Mediterranean region and is now well distributed worldwide (Watt and Breyer-Brandwijk, 1962). In South Africa, $R$. graveolens which belongs to the family of Rutaceae, is commonly grown as herbs in gardens and has become well established in some parts of the country such as the Calvinia District where it iswell known as a medicinal plant (Van Wyk et al., 1997; Rood, 1994; Palmer and Pitman, 1972). Locally, R. graveolens is known as "wynruit or binnewortel" in Afrikaans and rue or herb of grace in English (Van Wyk et al., 1997). Ruta gravealens L. is a small evergreen, aromatic, woody perennial shrub of about a meter in height. The leaves are irregularly divided into several leaflets which are variable in size and shape. Clusters of small yellow flowers are found at or near the tips of the branches. Each flower has four yellow petals with irregularly toothed margins. The fruits of the plant species are small four lobed capsules which are heavily covered with glands (!auk et al., 2004; Van Wyk et al., 1997). Rue has been used as a medicinal herb for centuries. Leaf infusions are taken for fever, convulsions and fits in children, and for epilepsy and hysteria (Van Wyk et al., 1997; Watt, 1967). Alcoholic tinctures have been used to treat, respiratory problems and heart diseases (Ojala et al., 2000; Rood, 1994; Watt and Breyer-Brandwijk, 1962). Decoctions have been used to ease child birth (Browner, 1985). Toothache and earache have been treated with briused leaves (Rood, 1994; Wat 1967; Watt and Breyer-Brandwijk, 1962). The plant is traditionally used in Europe for a wide range of aihnents, ranging from hysteria to rhewnatism (Atta and Alkofahi, 1998; Grieve, 1967). Ithas been used as a contraceptive (Browner, 1985) and also to relieve symptoms of hang over (Atta and Alkofahi, 1998). Despite the wide use of Ruta graveolens by traditional medicine practitioners and homeopaths in the treatment and management of epilepsy (Van Wyk et al., 1997; Grieve, 1967; Watt and BreyerBrandwijk, 1962), little or no information exists in any literature about studies on the possible mechanism of the anticonvulsant effect of the plant species. The main aim of this study was, therefore, to verify the anticonvulsant effect and also to investigate the possible mechanism involved of the leaf methanol extract of Ruta graveolens $\mathrm{m}$ mice. Phytochemical qualitative analysis, acute toxicity and HPLC studies of the plant species were also carried out.

\section{Materials and methods}

Plant material: Fresh leaves of Ruta graveolens L. were bought from the Nursery, Kirstenbosch Botanical Garden, South Africa, in February 2011. A sample of the collected leaves was identified by 1.1r F. Weitz, a taxonomist, in the Department of Biodiversity and Consenration Biology, University of the Western Cape and a voucher specimen (No. 6974) was deposited in the University's Herbarium.

Preparation of the methanol plant extracts: Fresh leaves were separated from branches of the plant and weighed $(222.5 \mathrm{~g})$. They were then washed with distilled water, air dried for an hour and dried in an oven at $40^{\circ} \mathrm{C}$ for 2 days. The dried leaves were milled into coarse powder $(177.6 \mathrm{~g}$ ) using the hammer mill. For the preparation of the leaf methanol extract, $25 \mathrm{~g}$ of the dried powder of Ruta graveolens was 
extracted in a Soxhlet extractor with $500 \mathrm{~mL}$ of methanol for $5 \mathrm{~h}$. The resultant methanol filtrate was evaporated to dryness using a Buchi RE 11 rotavapor and Buchi 461 water bath. A yield of $6.3 \mathrm{~g}$ extract of crude methanol was obtained and presenred in a refrigerator. Fresh solution of the crude leaf methanol extract was prepared on each day of the experiment by dissolving a weighed quantity of the methanol extract in a small volume of dimethylsulfoxide (DMSO) and made up to the appropriate volwne with physiological saline. The solutions were administered intraperitoneally (i.p.) to mice in a volume of $1 \mathrm{~mL} / \mathrm{l}$ oo g of animals.

Animals: Male albino mice bred in the Animal House of the Discipline of Pharmacology, School of Pharmacy, University of the Western Cape, South Africa, weighing between $18 \mathrm{~g}$ and $30 \mathrm{~g}$ were used in groups of eight per dose of plant extract or drug. They had free access to food and water ad libitum. All animals were fasted for $16 \mathrm{~h}$. during which they had access to water prior to the commencement of the experiments. Laboratory condition of temperature $\left(25 \pm 1^{\circ} \mathrm{C}\right)$ humidity and a $12 \mathrm{~h}$. light/12 $\mathrm{h}$ dark cycle were maintained at all times during the experiments. Each mouse was used only once in the experiments.

Drugs and chemicals: Pentylenetetrazole (PTZ, Sigma Chemical Co.), picrotoxin (Sigma Chemical Co.), N-methyl-DL-aspartic acid (NMDLA, Sigma Chemical Co.), phenobarbitone sodium (BDH Chemicals Ltd), 5,5 diphenylhydantoin sodium salt (Phenytoin, Sigma Chemical Co.), muscimol (Sigma Chemical Co.) and LY233053 (Sigma Chemical Co.) were all dissolved in physiological saline to appropriate volwnes. (+) Bicuculline (Sigma Chemical Co.) was suspended in a small volume of Tween 80 and adjusted to the appropriate volume with physiological saline. Diazepam (Valiwn, Roche, South Africa) was dissolved in a minimwn amount of propylene glycol and made up to the appropriate volwne with physiological saline. Dimethylsulfoxide (DMSO, Sigma Chemical Co.) solution was prepared by dissolving equal volwne, used to dilute the plant extract, in an appropriate volume of physiological saline. All drugs were injected intraperitoneally (i.p.) in a volwne of $1 \mathrm{~mL} / \mathrm{l}$ oo $\mathrm{g}$ of animal. Equal volume injections of the appropriate vehicles such as physiological saline and DMSO were given to the control animals. The plant extract and drug solutions were prepared fresh on the days of the experiment. The doses and pre-treatment times of the leaf methanol extract and the standard antiepileptic drugs used were obtained from preliminary studies in laboratory. The pre-treatment times following the administration of pentylenetetrazole, bicuculline, picrotoxin or NlvIDLA were $15 \mathrm{~min}$ (plant extract), $10 \mathrm{~min}$ (phenobarbitone ), $20 \mathrm{~min}$ (diazepam), 20 min (phenytoin), 30 min (LY233053), $1 \mathrm{~h}$ (muscimol) and $15 \mathrm{~min}$ (DMSO solution).

Phytochemical qualitative analysis: The dried powdered leaf of the plant species was analysed for various chemical compounds using standard protocols and well established methods (Ikhiri et al., 1992; Harbome, 1984). 


\section{HPLC analysis}

Chromatographic system: Beckman HPLC consisting of double pump Programmable system Solvent Module model 126; Diode Array detector module model 160; Samstmg computer 386 with management System Gold (Gold V 601) software applied by Beckman; column. Cl 8 Bondapak $5 \mu \mathrm{rn}$ and dimentions (250x 4.6 mm').

Chromatographic conditions: Mobile phase, solvent A: $1 \%$ acetic acid; solvent B: methanol, Mode: gradient flow rate, 1 min min-1 $^{1}$; injection volwne, $10 \mu \mathrm{L}$; detector, $1 \mathrm{~N}$ at $350 \mathrm{~nm}$. The HPLC operating conditions were programmed to give the following: o min, solvent B: 20\%; 5 min, solvent B: 40\%; 15min, solvent B: 60\%; 20 min, solvent B: $80 \%$ and $27 \mathrm{~min}$. The run rate was $30 \mathrm{~min}$.

Anticonvulsant activity assessment: The method described by Vellucci and Webster (1984) and modified by Arnabeoku and Chikuni (1993), was used to assess the anticonvulsant activity of the leaf methanol extract of Ruta graveolens. The mice were kept singly in transparent perspex mice cages $30 \mathrm{~min}$ before the start of the experiment to get used to their new environment. Control animals were pretreated for 15 min with physiological saline (0.25 mL, i.p.) and then standard convulsant agents, such as, PTZ (95 mg kg-', i.p.), bicuculline (40 mg kg-', i.p.), picrotoxin (12 mg kg-', i.p.) or NMDLA (400 $\mathrm{mg} \mathrm{kg-1}^{1}$, i.p.) was administered to induce convulsion in the mice. The animals ere obsenred for 30 min for tonic convulsion. Seizures were manifested as tonic hind- limb extensions. The time of the onset of seizures and proportion of animals convulsing or not convulsing were obtained during the $30 \mathrm{~min}$ period of obsenration. Test animals, eight per group, were pre-treated with either the leaf methanol extract of the plant species (25-100 mg kg-', i.p.), phenobarbitone (12 mg kg-', i.p.), diaz.eparn (o.5 mg kg-', i.p.), phenytoin (30 mg kg-', i.p.), muscirnol (o.6-2 mg kg-', i.p) or LY233053 (1-5 mg kg-', i.p.) prior to the adininistration of any of the convulsant agents. The animals were also obsenred for $30 \mathrm{~min}$ for tonic convulsion. The time of the onset of seizures and proportion of animals convulsing or not convulsing were obtained during the $30 \mathrm{~min}$ period of obsenration. The experiment was repeated with another group of eight mice pretreated for 15 min with DMSO (0.25 mL, i.p.) prior to the adininistration of any of the convulsant agents. The ability of the plant extract to prevent or prolong the latency or onset of the tonic hind limb extensions was taken as an indication of anticonvulsant activity (Amabeoku and Chikuni, 1993; Amabeoku et al., 1998). All the experiments were carried out in a quiet laboratory at an ambient temperature of $25 \pm 1^{\circ} \mathrm{C}$ and between 8.30 arn-17.00 pm on each a day of the experiment.

Acute toxicity study: The modified methods of Lorke (1983) by Ojewole (2006) and El Hilaly et al. (2004) were used for the acute toxicity study of $R$. graveolens. The acute toxicity study was carried out to establish the median lethal dose $\left(\mathrm{LD}_{50}\right)$ of the plant extract. Mice were fasted for 16 hours and then randomLy divided into groups of eight mice per cage . Graded doses of the plant extract (1 oo, 200, 400, 800, 
$1200,1600,2000,2400,2800,3200,3600$ and $\left.4000 \mathrm{mg} \mathrm{kg}-{ }^{\prime}\right)$ were separately administered orally by means of a bulbed steel needle to mice in each test group. The control group received $0.25 \mathrm{~mL}$ (p.o.) of physiological saline by means of a bulbed steel needle. The mice were then allowed free access to food and water and obsenred for 5 days for signs of acute toxicity including death. If necessary, at the end of the 5 days obsenration period, log dose-response cwves would be constructed for the plant extract from which the median lethal dose would be calculated.

Statistical Analysis: The data on the onset of tonic convulsion were analysed using one way analysis of Variance (ANOVA) followed by Dunnett's multiple comparison test (Graph Pad Prism, version 5.0, Graph Pad software, Inc., San Diego Cap 2130, USA). The number of animals convulsing was analysed using the chi-squared test (Bienvenu et al., 2002). The data obtained were expressed as Mean \pm SEM. P values of less than $5 \%(\mathrm{p}<0.05)$ were considered statistically significant .

Ethical consideration: The experimental protocol used in this study was approved (07/04/31) by the Uinversity of the Western Cape Ethics Committee, Bellville 7535, South Africa and conforms with the University's Regulations Act concerning animal experiments.

\section{Results}

Phytochemical analysis: The qualitative phytochemical analysis of the dried powdered leaf of Ruta graveolens showed that the chemical constituents in the plant species include tannins, saponins, cardiac glycosides, alkaloids, flavonoids and triterpene steroids.

\section{Anticonvulsant activity}

Effect of leaf methanol extract of Ruta graveolens on pentylenetetrazole (ptz)-induced seizures: Pentylenetetrazole (PTZ, $95 \mathrm{mg} \mathrm{kg-',} \mathrm{i.p.)} \mathrm{produced} \mathrm{tonic}$ convulsion in $100 \%$ of the animals tested. Leaf methanol extract of Ruta graveolens (25-50 mg kg-', i.p.) did not significantly affect the onset or incidence of the tonic convulsion elicited by PTZ (95 mg kg-', i.p.). Doses of 25 and $50 \mathrm{mg} \mathrm{kg}^{-}$(i.p.) of $R$. graveolens protected 25 and $37.5 \%$ of the mice against PTZ (95 $\mathrm{mg} \mathrm{kg-}^{1}$, i.p.)induced tonic convulsion, respectively.

The onset of the tonic convulsion produced by PTZ (95 mg kg-', i.p.) was significantly prolonged by $R$. graveolens (100 $\mathrm{mg} \mathrm{kg-',} \mathrm{i.p.).} \mathrm{The} \mathrm{number} \mathrm{of} \mathrm{animals}$ convulsing as a result of PTZ (95 mg kg- ${ }^{1}$, i.p.) was also significantly reduced by R. graveolens (100 mg kg-', i.p.) which protected $62.5 \%$ of the animals against the seizures. Phenobarbitone (12 mg kg-1, i.p.) and muscimol (2 mg kg-1 , i.p.) significantly delayed the onset of PTZ (95 mg kg-', i.p.)-elicited tonic convulsion and also significantly reduced the number of animals convulsing as a result of the tonic convulsion. Phenobarbitone (12 $\mathrm{mg} \mathrm{kg}^{-}$, i.p.) and muscimol (2 mg kg-', i.p.) 
protected 75 and $87.5 \%$ of mice against the tonic convulsion, respectively. Diazeparu (0.5 mg kg-', i.p.) completely protected all the animals used against PTZ (95 mg kg-', i.p.)-elicited tonic convulsion. Like leaf methanol extract of $R$. graveolens (25 mg kg-', i.p.), muscimol (o.6 mg kg-', i.p.) did not significantly affect the onset or incidence of the 10 tonic convulsion elicited by PTZ (95 mg kg-', i.p.). Muscimol (o.6 mg kg-1, i.p.) protected 25 of mice against the tonic convulsion. However, combined therapy of leaf methanol extract of $R$. graveolens (25 mg kg-1, i.p.) and muscimol (o.6 mg kg-', i.p.) significantly prolonged the onset of the tonic convulsion produced by PTZ (95 mg kg-', i.p.) and significantly reduced the number of animals convulsing. The combined therapy protected $87.5 \%$ of the animals against the tonic convulsion. DMSO (0.25 mL, i.p.) or phenytoin (30 mg kg-', i.p.) did not significantly affect the onset or incidence of the tonic convulsion elicited by PTZ (95 mg kg-', i.p.) (Table 1).

\section{Effect of leaf methanol extract of Ruta graveolens on bicuculline-}

induced seizures: Bicuculline (40 $\mathrm{mg} \mathrm{kg-}^{1}$, i.p.) induced tonic convulsion in all the eight mice used for the experiment. Leaf methanol extract of $R$. graveolens (100 mg kg-', i.p.) significantly delayed the onset of bicuculline (40 $\mathrm{mg} \mathrm{kg-}^{1}$, i.p.)induced tonic convulsion and also significantly reduced the nwnber of animals convulsing. $R$. graveolens (100 $\mathrm{mg} \mathrm{kg-}^{1}$, i.p.) protected $75 \%$ of the animals against the convulsion produced by bicuculline (40 mg kg-', i.p.). Similarly, $50 \mathrm{mg} \mathrm{kg-'} \mathrm{(i.p.)} \mathrm{of}$ $R$. graveolens significantly delayed the onset of the tonic convulsion elicited by bicuculline (40 mg kg-1, i.p.). However, the incidence of the tonic convulsion was not significantly affected by R.graveolens (50 mg kg-', i.p.) which protected $50 \%$ of $\mathrm{m}$ ice against the convulsion.

R. graveolens (25 mg kg-1, i.p.) neither significantly altered the onset nor the incidence of bicuculline (40 mg kg-1, i.p.)-elicited tonic convulsion. Phenobarbitone (12 mg kg-', i.p.), diazeparu (0.5 mg kg-', i.p.) or muscimol (2 mg kg-', i.p.) significantly delayed the onset of tonic convulsion produced by bicuculline (40 mg kg-', i.p.) and also significantly reduced the nwnber of animals convulsing. Phenobarbitone (12 mg kg-', i.p.), diazeparu (o.5 mg kg-', i.p.) or muscimol (2 mg kg-', i.p.) protected $87.5 \%$ of mice against bicuculline (40 $\mathrm{mg} \mathrm{kg-}$, i.p.)-elicited tonic convulsion.

Neither phenytoin (30 mg kg-', i.p.), DMSO (o.25 rnL, i.p.) nor muscimol (o.6 mg kg-1 i.p.) significantly altered the onset or incidence of bicuculline (40 $\mathrm{mg} \mathrm{kg-1}^{1}$, i.p.)induced tonic convulsion. The combined therapy of leaf methanol extract of $R$. graveolens (25 mg kg-', i.p.) and muscimol (o.6 mg kg-', i.p.) significantly delayed the onset of the tonic convulsion produced by bicuculline (40 $\mathrm{mg} \mathrm{kg-',} \mathrm{i.p.)} \mathrm{and}$ significantly reduced the number of animals convulsing. The combined therapy protected $62.5 \%$ of the animals against the tonic convulsion (Table 2). 
Effect of leaf methanol extract of Ruta Graveolens (RG) on picrotoxin (PIC)-induced seizures: Picrotoxin (15 mg kg-1, i.p.) produced tonic convulsion within $10.75 \mathrm{~min}$ in all the mice used. Leaf methanol extract of Ruta graveolens (50$100 \mathrm{mg} \mathrm{kg-',} \mathrm{i.p.)} \mathrm{significantly} \mathrm{prolonged} \mathrm{the} \mathrm{onset} \mathrm{of} \mathrm{the} \mathrm{tonic} \mathrm{convulsion} \mathrm{produced} \mathrm{by}$ picrotoxin (15 mg kg-', i.p.).

Table 1: Effect of leaf methanol extract of Rutagraveolens (RG) on pentylenetetrazole (PTZ)-induced seizures in mice Dose $\left(\mathrm{mg} \mathrm{kg}^{-1}\right)$

\begin{tabular}{|c|c|c|c|c|c|c|c|c|c|}
\hline PTZ & $\mathrm{RG}$ & $\begin{array}{l}\text { Pheno } \\
\text { barbitone }\end{array}$ & Diazepam & Phernytoin & DMSO & Muscimol & $\begin{array}{l}\text { No convulsed/ } \\
\text { no used }\end{array}$ & $\begin{array}{l}\text { Percentage } \\
\text { protection }(\%)\end{array}$ & $\begin{array}{l}\text { convulsion (min) } \\
\text { Mean } \pm \text { SEM }\end{array}$ \\
\hline 95 & - & - & - & - & - & - & $8 / 8$ & 0.0 & $5.25 \pm 0.70$ \\
\hline 95 & 25 & - & - & - & - & - & $6 / 8$ & 25.0 & $5.67 \pm 0.70$ \\
\hline 95 & 50 & - & - & - & - & & $5 / 8$ & 37.5 & $16.13 \pm 4.52$ \\
\hline 95 & 100 & - & - & - & - & - & $3 / 8^{+}$ & 62.5 & $26.13 \pm 3.00^{\circ}$ \\
\hline 95 & - & 12 & - & - & - & - & $2 / 8^{+1}$ & 75.0 & $25.63 \pm 2.99^{\circ}$ \\
\hline 95 & - & - & 0.5 & - & - & - & $0 / 8^{1+1+}$ & 100.0 & $0^{*}$ \\
\hline 95 & - & - & - & 30 & - & - & $8 / 8$ & 0.0 & $4.25 \pm 0.35$ \\
\hline 95 & - & - & - & - & $0.25 \mathrm{~mL}$ & - & $8 / 8$ & 0.0 & $4.88+0.55$ \\
\hline 95 & - & - & - & - & - & 2 & $1 / 8^{+1+}$ & 87.5 & $29.10 \pm 4.80^{\circ}$ \\
\hline 95 & - & - & - & - & - & 0.6 & $6 / 8$ & 25.0 & $11.25 \pm 1.72$ \\
\hline 95 & 25 & - & - & - & - & 0.6 & $1 / 8^{1+1}$ & 87.5 & $27.78 \pm 3.62^{*}$ \\
\hline
\end{tabular}

Table 2: Effect of leaf methanol extract of Rutagraveolens (RG) on bicuculline (BIC)-induced seizure in mice

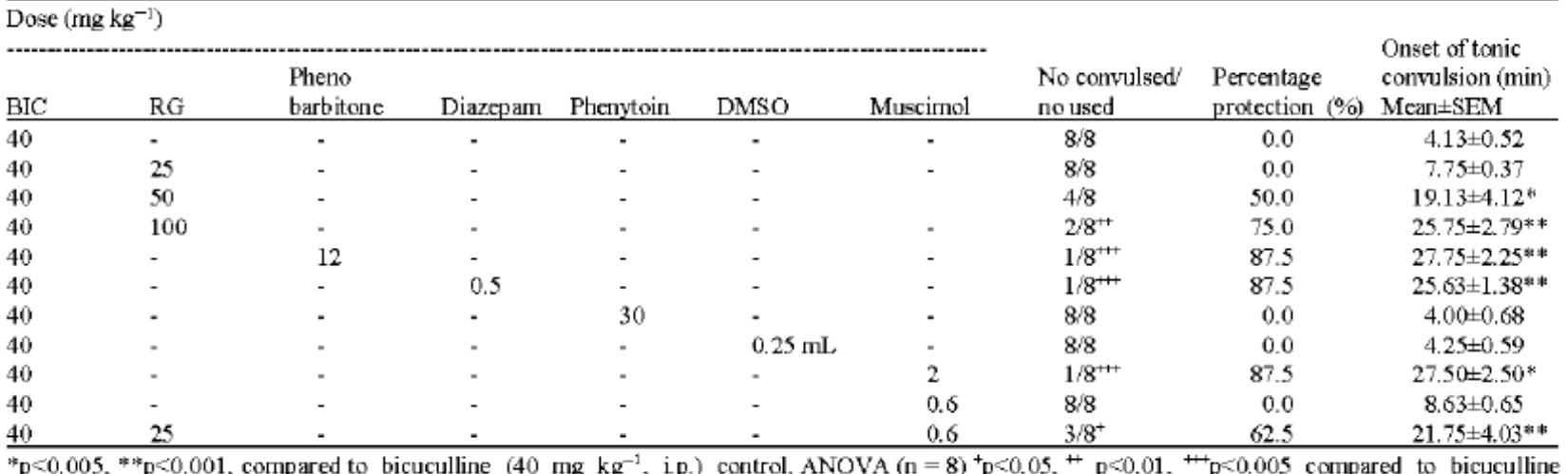
(40 $\mathrm{mg} \mathrm{kg}^{-1}$, i.p.) control, Chi-squared test $(\mathrm{n}=8)$ DMSO: Dimethylsulfoxide

Table 3: Effect of leaf methanol extract of Ruta Graveolens (RG) on picrotoxin (PIC)-induced seizures in mice

\begin{tabular}{|c|c|c|c|c|c|c|c|c|c|}
\hline \multicolumn{7}{|c|}{ Dose (mg kg $\left.{ }^{-1}\right)$} & \multirow[b]{2}{*}{$\begin{array}{l}\text { No convulsed } \\
\text { no used }\end{array}$} & \multirow[b]{2}{*}{$\begin{array}{l}\text { Percentage } \\
\text { protection }(\%)\end{array}$} & \multirow{2}{*}{$\begin{array}{l}\text { Onset of tonic } \\
\text { convulsion (min) } \\
\text { Mean } \pm \text { SEM }\end{array}$} \\
\hline BIC & $\mathrm{RG}$ & DMSO & $\begin{array}{l}\text { Pheno- } \\
\text { barbitone }\end{array}$ & Diaze-pam & Pheny-toin & Musci-mol & & & \\
\hline 15 & - & - & - & - & - & - & $8 / 8$ & 0.0 & $10.75 \pm 0.75$ \\
\hline 15 & 25 & - & - & - & - & - & $8 / 8$ & 0.0 & $10.88 \pm 0.44$ \\
\hline 15 & 50 & - & - & - & - & & $3 / 8^{+}$ & 62.0 & $23.50 \pm 3.17^{*}$ \\
\hline 15 & 100 & - & - & - & - & - & $2 / 8^{++}$ & 75.0 & $26.88 \pm 2.29^{k 11 k}$ \\
\hline 15 & - & $0.25 \mathrm{~mL}$ & - & - & - & - & $8 / 8$ & 0.0 & $11.13 \pm 0.88$ \\
\hline 15 & - & - & 12 & - & - & - & $0 / 8^{+1+}$ & 100.0 & $0^{* 4 *}$ \\
\hline 15 & - & - & - & 0.5 & - & - & $0 / 8^{+m}$ & 100.0 & $0^{* *}$ \\
\hline 15 & - & - & - & - & 30 & - & $8 / 8$ & 0.0 & $11.00 \pm 0.65$ \\
\hline 15 & - & - & - & - & - & 2 & $1 / 8^{+m}$ & 87.5 & $29.13 \pm 0.88^{4: 8}$ \\
\hline 15 & - & - & - & - & - & 0.6 & $5 / 8$ & 37.5 & $18.35 \pm 3.98$ \\
\hline 15 & 25 & - & $=$ & . & - & 0.6 & $2 / 8^{++}$ & 75.0 & $22.60 \pm 3.98^{*}$ \\
\hline
\end{tabular}


These doses of the plant extract also significantly reduced the number of animals convulsing. $R$. graveolens (5O $\mathrm{mg} \mathrm{kg-}^{1}$, i.p.) and ( $\mathrm{OOO} \mathrm{mg} \mathrm{kg-'}$, i.p.) protected 62.5 and $100 \%$ of mice against picrotoxin-induced tonic convulsion, respectively. Dose of $25 \mathrm{mg} \mathrm{kg}-$ ', i.p.) of the leaf methanol extract of $R$. graveolens did not significantly affect the onset or incidence of picrotoxin (15 $\mathrm{mg} \mathrm{kg}^{1}$, i.p.)-induced tonic convulsion. Phenobarbitone (12 mg kg-1, i.p.), diazeparu (0.5 mg kg-', i.p.) or muscimol (2 mg kg- ,' i.p.) significantly delayed the onset of tonic convulsion produced by picrotoxin (15 $\mathrm{mg} \mathrm{kg-'}$, i.p.) and also significantly reduced the number of animals convulsing. Muscimol (o.6 mg kg-', i.p.) did significantly alter the onset or incidence of picrotoxin (15 mg kg-1, i.p.)induced tonic convulsion. but protected $37.5 \%$ of mice against the tonic convulsion. However, the combined therapy of leaf methanol extract of $R$. graveolens (25 mg kg-', i.p.) and muscimol (o.6 mg kg-', i.p.) significantly delayed the onset of the tonic convulsion produced by picrotoxin ( $15 \mathrm{mg} \mathrm{kg-',} \mathrm{i.p.)} \mathrm{and} \mathrm{significantly} \mathrm{reduced} \mathrm{the} \mathrm{number} \mathrm{of} \mathrm{animals}$ convulsing. The combined therapy protected $75 \%$ of the animals against the tonic convulsion. DMSO (o. $25 \mathrm{~mL}$, i.p.) or phenytoin (30 mg kg-', i.p.) did not significantly affect the onset or incidence of picrotoxin (15 mg kg-', i.p.)-induced tonic convulsion (Table 3).

Effect of leaf methanol extract of Ruta graveolens (RG) On N-methyl-DL aspartic acid (NMDLA)-induced seizures: NlvIDLA (400 $\mathrm{mg} \mathrm{kg-1}^{1}$, i.p.) produced tonic convulsion within $2.63 \mathrm{~min}$ in $100 \%$ of mice used. In all the doses (25-100 mg kg-', i.p.) used, the leaf methanol extract of $R$. graveolens did not significantly affect the onset of NlvIDLA (400 $\mathrm{mg} \mathrm{kg-}^{1}$, i.p.)-induced tonic convulsion or the nwnber of animals convulsing. Phenobarbitone (12 mg kg-', i.p.), diazeparu (0.5 mg kg-', i.p.), phenytoin (30 mg kg-', i.p.) or DMSO (0.25 mL, i.p.) also did not significantly affect the onset of NMDLA (400 mg kg-', i.p.)-induced tonic convulsion or the number of animals convulsing. LY 233053 (5 mg kg-', i.p.) significantly prolonged the onset of the tonic convulsion produced by NMDLA (400 mg kg-', i.p.) and significantly reduced the number of animals convulsing. Dose of $5 \mathrm{mg} \mathrm{kg-}^{-1}$ (i.p.) of LY 233053 protected $87.5 \%$ of mice against NMDLA (400 mg kg-', i.p.)-induced tonic convulsion. LY 233053 (I mg kg-', i.p.) did not significantly affect the onset or incidence of NMDLA (400 mg kg-', i.p.)induced tonic convulsion.

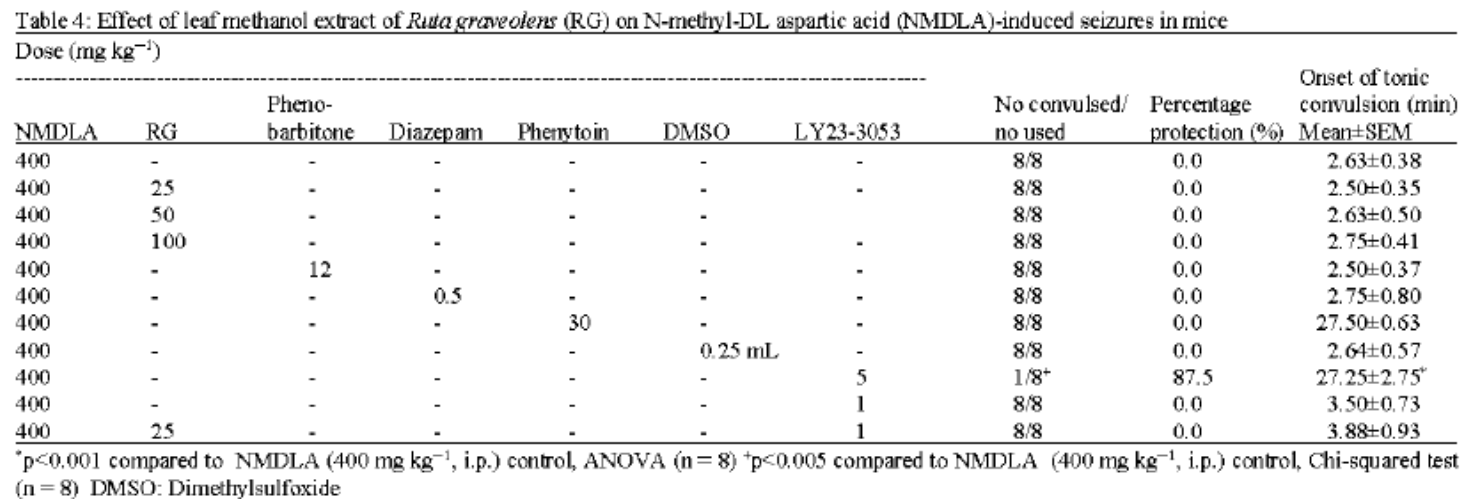




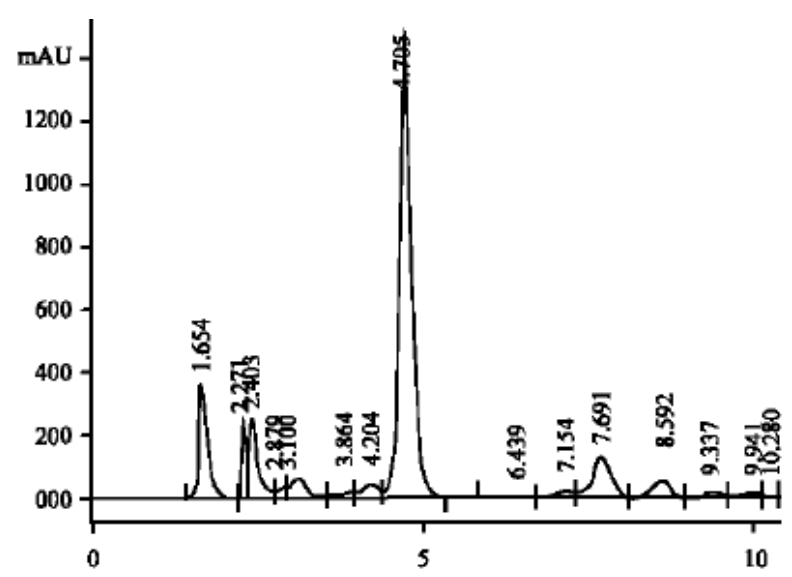

Fig. 1: HPLC chromatogram of leaf methanol extract of Ruta. graveolens

Furthermore, the combined treatment of the leaf methanol extract of $R$. graveolens (Ioo mg kg-', i.p.) and LY233053 (I mg kg-', i.p.) also did not significantly affect the onset or incidence of the tonic convulsion produced by NMDLA (400 mg kg-', i.p.) (Table 4).

Acute toxicity: The doses of 100-4000 mg kg-' (p.o.) of the leaf methanol extract of Ruta graveolens caused no deaths and there were no signs of acute toxicity. Since the highest dose tested was $4000 \mathrm{mg} \mathrm{kg-'} \mathrm{(p.o.),} \mathrm{this} \mathrm{is} \mathrm{taken} \mathrm{as} \mathrm{the} \mathrm{no-adverse-effect-level}$ (NOAEL). The LD50 obtained for $R$. graveolens following oral administration was probably greater than $4000 \mathrm{mg} \mathrm{kg-}^{1}$ in mice.

HPLC analysis: The chromatographic spectrum of the leaf methanol extract of Ruta graveolens obtained revealed major characteristic peaks at the following retention times (mni): 1.654, 2.271, 2.403, 4.705 and 7.691 min (Fig. 1). 139

\section{Discussion}

The study investigated the anticonvulsant effect of the leaf methanol extract of $R$. graveolens inmice and the possible involvement of GABA.

In this study, PTZ (95 mg kg-', i.p.), bicucullnie (40 mg kg-', i.p.), picrotoxni (15 mg kg-', i.p.) and NMDLA (400 mg kg-', i.p.) all produced tonic convulsions inthe mice used. The leaf methanol extract of Ruta graveolens (50-100 mg kg-', i.p.) antagonized the tonic convulsions produced by PTZ, bicuculline and picrotoxin but did not affect NlvIDLA-induced tonic convulsion. Similarly, phenobarbitone (12 mg kg1, i.p.), diazepam (o.5 mg kg-', i.p) and muscimol (2 mg kg-',i.p.) antagonized the tonic convulsions produced by PTZ, bicuculline and picrotoxin but did not affect the tonic convulsion produced by NlvIDLA. Phenytoin (30 mg kg-1, i.p.) did not affect the tonic convulsions produced by either of the four convulsant agents. LY 23350 (5 mg kg-', i.p.) antagonized NMDLA-niduced tonic convulsion. 
According to Meldrum (1975), Olsen (1981), Czuczwar and Patsalos (2001), Waller et al. (2005) and Rang et al. (2012), gamma amniobutyric acid (GABA), a major inhibitory neurotransmitter, with its receptors, GABAA receptors and glutamic acid, an excitatory neurotransmitter with its receptors, NlvIDA receptors in the brain may be implicated in epilepsy. They reported that the enhancement and inhibition of GABA mediated inhibition at GABAA receptors in the brain antagonizes and causes convulsion, respectively. They also reported that the enhancement and inhibition of glutamic acid neurotransmission at NlvIDA receptors in the brain enhances and antagonizes convulsion, respectively. According to Rang et al. (2012) and De Sano et al. (1999), pentylenetetrazole acts by blocking GABAA receptors thus inhibiting GABA mediated inhibition. Phenobarbitone and diazepam, standard antiepileptic drugs (Rang et al., 2012; Waller et al., 2005) are known to act by enhancing GABA neurotransmission in the brain through the GABAA receptor-chloride ionophore complex. In the present study, phenobarbitone and diazepam antagonized PTZinduced tonic convulsion and this may probably be as a result of their enhancing GABA neurotransmission. Phenytoin, another standard anticonvulsant, did not antagonize the tonic convulsion produced by PTZ. According to Rang et al. (2012) and Waller et al. (2005), phenytoin produces its antiepileptic effect by blocking the entry of sodium ions into brain cells and thus, inhibiting the generation of repetitive action potential. Muscimol effectively antagonized PTZ-induced tonic convulsion in mice. Muscimol, a selective and powerful GABAA receptor agonist, acts by interacting with GABAA receptors inthe brain to mimic the effects of GABA (Rang et al., 2012; Lloyd, 1985). The leaf methanol extract of $R$. graveolens was shown to antagonize the tonic convulsion produced by PTZ. It is therefore, possible to suggest that $R$. graveolens may be affecting GABA mechanism to produce its anticonvulsant activity. The combined therapy of very low doses of $R$. graveolens and muscimol which were in themselves, ineffective, significantly antagonized PTZ-induced tonic convulsion. This supports the assertion that GABA mechanism may be involved in the anticonvulsant activity of $R$.graveolens.

In the present study, bicuculline induced tonic convulsion in mice. According to Rang et al. (2012), Nicoll (2001) and Lloyd (1985), bicuculline, a potent GABAA receptor antagonist, produces its convulsant activity by blocking GABAA receptors and this inhibits GABA neurotransmission in the brain. Phenobarbitone and diazeparn, both known to enhance GABA neurotransmission in the brain, antagonized bicucullineinduced tonic convulsion. Similarly, muscimol, a specific GABAA receptor agonist, antagonized the tonic convulsion produced by bicuculline. The leaf methanol extract of $R$. graveolens also antagonized bicuculline- induced tonic convulsion. Phenytoin, known to exert its antiepileptic effects by blocking sodiwn ion entry into the brain, did not antagonize bicuculline-induced tonic convulsion. The combined therapy of very low doses of muscimol and leaf methanol extract of the plant species, which when given separately, were ineffective against bicuculline-induced convulsion, effectively antagonized the tonic convulsion. These findings further support the claim that

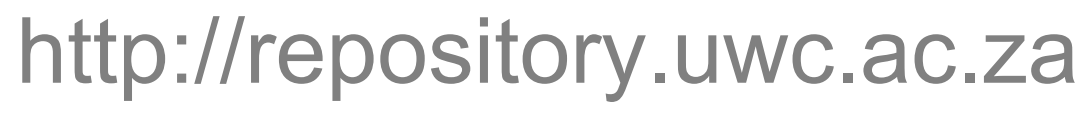


activation of GABA mechanisms may underpin the anticonvulsant activity of $R$. graveolens.

According to Rang et al. (2012), picrotoxin produces convulsion by blocking GABAA receptor-linked chloride ion channel to prevent the entry of chloride ions into the brain and thus inhibit GABA neurotransmission. In this study, picrotoxin produced tonic convulsion in mice which was antagonized by phenobarbitone and diazepam, both of which are known to enhance GABA neurotransmission in the brain. Muscimol, a specific GABAA receptor agonist, known to mimic the effect of GABA at GABAA receptors, also effectively antagonized picrotoxin-induced tonic convulsion. The leaf methanol extract of $R$. graveolens also antagonized picrotoxin- induced tonic convulsion. However, phenytoin whose anticonvulsant effect depended on its blocking of sodium ion entry into the brain, did not affect picrotoxin-induced tonic convulsion. The combined therapy of low doses of muscimol and leaf methanol extract of $R$. graveolens, known to be ineffective when given separately, antagonized the tonic convulsion produced by picrotoxin. These findings also show that the leaf methanol extract of $R$. graveolens may be enhancing GABA neurotransmission to produce its anticonvulsant activity. N-Methyl-DL-aspartic acid (NMDLA) produces its anticonvulsant effects by acting as a specific agonist at NlvIDA receptors to mimic the action of glutamate, the excitatory neurotransmitter which also acts at the same receptors in the brain (Rang et al., 2012; Besancon et al., 2008; Chapman and Meldium, 1993). In the present study, phenobarbitone and diazepam, both of \Vhich are known to enhance GABA neurotransmission in the brain, did not affect NlvIDLAInduced tonic convulsion in mice. Muscimol, a specific GABAA receptor agonist known to mimic the effects of GABA at this receptor, also did not affect the tonic convulsion produced by NlvIDLA. The leaf methanol extract of $R$. graveolens, in all the doses used, did not alter Nlv1DLA-induced tonic convulsion. Phenytoin known to exert its anticonvulsant effect by blocking sodiwn ion entry into the brain also did not alter the tonic convulsion produced by NMDLA. LY233053, a competitive NlvIDA receptor antagonist, which acts by blocking the effect of glutamate at NlvIDA receptor (Borowicz et al., 1996; Madden et al., 1992) effectively antagonized NlvIDLA-induced tonic convulsion. The combined therapy of low doses of muscimol and LY 233053 which were in themselves ineffective against NlvIDLAinduced tonic convulsion, did not affect the convulsion produced by NlvIDLA. This shows that glutamate mechanisms may not be involved in the anticonvulsant activity of $R$. graveolens. In the present study, the phytochemical qualitative analysis of the dried leaf extract of $R$. graveolens revealed the presence of the following chemical components: saponins, tannins, cardiac glycosides, alkaloids, triterpene steroids and flavonoids. Abu Safieh et al. (1986), Mimaki et al. (1997) and Muazu and Kaita (2008) from their various studies, have shown the anticonvulsant effect of alkaloids. Fwthermore, flavonoids have also been shown to have anticonvulsant effect (Ibrahim et al., 2008; Van Heerden et al., 2002). According to the studies of Singh et al. (2012) and Chauhan et al. (1988), saponin and triterpene steroids also have anticonvulsant effects. Since $R$. graveolens has been shown to 
contain alkaloids, flavonoids, saponins and triterpene steroids a111ongst other chemical components, it is possible, therefore, that these secondary metabolites may be contributing to the anticonvulsant activity of the plant species.

The data obtained from the acute toxicity study carried out showed that following oral administration of the leaf methanol extract to mice, the $\mathrm{LD}_{50}$ may be greater than $4000 \mathrm{mg} \mathrm{kg-1}$. The leaves of $R$. graveolens are given orally as an infusion by traditional medicine practitioners (Van Wyk et al., 1997). Therefore, the high $\mathrm{LD}_{50}$ obtained for the plant species following oral administration indicates that it 1 s safe in and non-toxic to the animals. The HPLC fingerprint obtained for $R$. graveolens revealed the presence of characteristics peaks at $350 \mathrm{~nm}$ which may be used to identify the exact species of the plant.

\section{Conclusion}

The data obtained from this study indicate that the leaf methanol extract of $R$. graveolens has anticonvulsant activity which may be underpinned by enhancement of GABA neurotransmission. Secondary metabolites such as saponins, triterpene steroids, alkaloids and flavonoids found in the leaves of the plant species may also in part be contributing to the anticonvulsant activity. These findings justify the use of $R$. graveolens by traditional medicine practitioners in the management and treatment of epilepsy. However, fwther studies are needed to elucidate the full mechanism(s) of the anticonvulsant activity of the plant species. Also additional toxicological studies are needed to determine the safety profile of $R$. graveolens.

\section{Acknowledgments}

The authors wish to thank the National Research Foundation, South Africa, for supporting the study financially (67983). We also wish to thank the seinor academic support staff of the Pharmacology Discipline, University of the Western Cape, Bellville, South Africa, 1.1r. V. Jeaven, for his valuable technical support. 


\section{References}

Abu Safieh, KA, D.M. Al-Eisawi , M.H Abu Zarga and S.S. Sabri, 1986. Chemical constituents of the flora of Jordan, II. Alkaloids of Leontic leontopetalum. J. Nat Prod., 49: 726-727.

Arnabeoku, G.J. and o. Chikuni, 1993. Cirnetidine-induced seizures in mice: Antagonism by some GABAergic agents. Biochem. Phannacol., 46: 2171-2175.

Arnabeoku, G.J., M.J. Leng and J.A Syce, 1998. Antimicrobial and anticonvulsant activities of Viscum capense. J. Ethnophannacol., 61: 237-241.

Atta, AH. and A Alkofahi, 1998. Anti-nociceptive and anti-inflammatory effects of some Jordanian medicinal plant extracts. J. Ethnophannacol., 60: 117-124.

Besancon, E., S. Guo, J. Lok, M. Tymianski and E.H. Lo, 2008. Beyond NMDA and AMPA glutamate receptors: Emerging mechanisms for ionic imbalance and cell death in stroke. Trends Phannacol. Sci., 29: 268-275.

Bienvenu, E., G.J. Arnabeoku, P.K. Eagles, G. Scott and E.P. Springfield, 2002. Anticonvulsant activity of aqueous extract of Leonotis leonurus. Phytomedicine, 9: 217-223.

Borowicz., K.K., M. Gasior, Z. Kleimok and S.J. Cmczwar, 1996. Competitive NlvIDAreceptor antagonists, LY 235959 and LY 233053, enhance the protective efficacy of various antiepileptic drugs against maximal Electroshock-induced seizures in mice. Epilepsia, 37: 618-624.

Browner, C.H., 1985. Plants used for reproductive health in Oaxaca Mexico. Econ. Bot., 39: 482-504.

Chapman, AG. and B.S. Meldnnn, 1993. Excitatory an1ino acid antagonists and epilepsy. Biochem. Soc. Trans., 21: 106-110.

Chauhan, AK., M.P. Dobhal and B.C. Joshi, 1988. A review of medicinal plants showing anticonvulsant activity. J. Ethnophannacol., 22: 11-23.

Czuczwar, S.J. and P.N. Patsalos, 2001. The new generation of GABA enhancers, potential therapeutics in the treatment of epilepsy. CNS Drugs, 15: 339-350.

De Sarro, A., V. Ceccheti, V. Fravolini, F . Naccari, o. Tabaniin and G. De Sarro, 1999. Effects of novel 6-desfluroquinolones and classic quinolones on pentylenetetrazole- induced seizures in mice. Antirnicrob. Agents Chemother, 43: 1729-1736.

El Hilaly, J., Z.H. Israili and B. Lyoussi, 2004. Acute and chronic toxicological studies of Ajuga iva in experimental animals. J. Ethnophannacol., 91: 4350.

Grieve, M., 1967. A Modem Herbal. Vol. 2. Hafner Publishing Co., London, UK. Harbome, J.B., 1984. Phytochemical Methods: A Guide to Modem Techniques of Plant Analysis. 2nd Edn., Chapman and Hall Ltd., London, ISBN: 0412255502, pp: 149-188.

Iauk, L., K. Magano, A Rapisarda, S. Ragusa and L. Maiolino et al., 2004. Protection against murine endotoxemia by treatment with Ruta chalepensis, a plant with anti-inflammatory properties. J. Ethnophannacol., 90: 267-272. 
Ibrahim, G., S. Abdulmumin, K Y. Musa and AH Yaro, 2008. Anticonvulsant activities of crude flavonoid fraction of the stem bark of Ficus sycomorus (Moraceae). J. Phannacol. Toxicol., 3: 351-356.

Ikhiri, K., D. Boureima and D. Dan-Kouloudo, 1992. Chemical screening of medicinal plants used in the traditional pharmacopoeia of Niger. Int. J. Phannacol., 30: 251-262.

Lloyd, K G., 1985. Neuroinhibitory Aminoacids. In: Principles of Medical Pharmacology, Kalant, H.,

W.H.E. Roschlau and E.M. Sellers (Eds.). University of Toronto Press, Toronto, pp: 235-238.

Lorke, D., 1983. A new approach to practical acute toxicity testing. Arch. Toxicol., 54: 275-287.

Madden, K.P., W.M. Clark, A Koch!Jar and J.A Zivin, 1992. Efficacy of LY233053, a competitive glutamate antagonist in experimental central nervous system ischemia. J. Neurosurg., 76: 106-110.

Meldrum, B. S., 1975. Epilepsy and gamma aminobutyric acid mediated inhibition. Int. Rev. Neurobiol., 17: 1-36.

Mimaki, Y., N. Toshirnizu, K Yanada and Y. Sashida, 1997. Anti-convulsion effects of choto-san and chotoko (Uncariae Uncis cam RamLus) in mice and identification of the active principles. Yakugaku Zasshi, 117: 1011-1021 [Article in Japnese].

Muazu, J. and A.H. Kaita, 2008. A review of traditional plants used in the treatment of epilepsy amongst the Hausa/Fulani tribes of northern Nigeria. Afr. J. Trad. CAM., 5: 387-390.

Nicoll, R A, 2001. Introduction to the Pharmacology of Central Nenrous System Drugs. In: Basic and Clinical Pharmacology, Katzung, B.G. (Ed.). 8th Edn., McGraw-Hill, New York, USA, pp: 255-263.

Ojala, T., S. Remes, P. Haansuu, H. Vuorela, R. Hiltunen, K. Haahtela and P. Vuorela, 2000. Antimicrobial activity of some cownarin containing herbal plants growing in Finland. J. EthnopharmacoL, 73: 299-305.

Ojewole, J.A.O., 2006. Antinociceptive, anti-inflammatory and

antidiabetic properties of Hypoxis hemerocallidea Fisch and C.A. Mey. (Hypoxidaceae) corm ['African Potato'] aqueous extract $\mathrm{m}$ mice and rats. J. Ethnophannacol., 103: 126-134.

Olsen, RW., 1981. GABA-benzodiazepine-barbiturate receptor interactions. J. Neurochem., 37: 1-13.

Palmer, E. and N. Pitman, 1972. Trees of Southern Africa. Balkema, Capetown, South Africa.

Rang, HP, M.M. Dale, J .M. Ritter, RJ. Flower and G. Henderson, 2012. Rang and Dale's Pharmacology. 7th Edn., Elsevier Churchill Livingstone, Edinburgh, pp: 448-458.

Rood, B., 1994. Uit Die Veldapteek I sl Edn. Tafelberg Publishers, Cape Town, South Africa.

Singh, D., B. Singh and RK Goel, 2012. Role of saponins for the anticonvulsant effect of adventitious roots of Ficus religiosa. Pharm. Biol., 50: 816-822. 
Van Heerden, FR, AM. Viljoen and S.P. Mohoto, 2002. A phytochemical investigation of Craterocapsa tarsodes, a plant used for the treatment of epilepsy by the Northem Sotho people of South Africa. South Afr. J. Bot, 68: 77-79.

Van Wyk, B.E., B. Van Oudtshoom and N. Gericke, 1997. Medicinal plants of South Africa. Briza Publications, Pretoria, South Africa, pp: 236-250.

Vellucci, S.V. and RA Webster, 1984. Antagonism of caffeine-induced seizures in mice by Ro 15-1788. Eur. J. Pharmacol., 97: 289-293.

Waller, D.G., AG. Renwick and K Hillier, 2005. Mediciml Pharmacology and Therapeutics. 2nd Edn., Elsevier Saunders, Edinburgh, pp: 305-317.

Watt, J.M. and M.G. Breyer-Brandwijk, 1962. The Medicinal and Poisonous Plants of Southern and Eastern Africa. 2nd Edn., E and S Liningstone Ltd., London, UK., Pages: 1457.

Watt, J.M., 1967. African plants potentially useful in mental health. Lloydia, 30: 122. 